\title{
Repeated regrouping of pair-housed heifers around puberty affects their behavioural and HPA axis reactivities
}

\author{
Satu RAUSSI ${ }^{\mathrm{a}, \mathrm{b} *}$, Alain BoISSY ${ }^{\mathrm{c}}$, Stéphane ANDANSON ${ }^{\mathrm{c}}$, \\ Jutta KAIHILAHTI $^{\mathrm{a}, \mathrm{b}}$, Philippe PRADEL ${ }^{\mathrm{d}}$, Isabelle VEISSIER ${ }^{\mathrm{c}}$
}

${ }^{a}$ MTT Agrifood Research Finland, Agricultural Engineering Research, 03400 Vihti, Finland

${ }^{\mathrm{b}}$ University of Helsinki, Faculty of Veterinary Medicine, Research Centre for Animal Welfare, Helsinki, Finland

${ }^{c}$ INRA, Centre de Clermont-Ferrand/Theix, URH-ACS, 63122 Saint-Genès-Champanelle, France

${ }^{d}$ INRA, Centre de Clermont-Ferrand/Theix, Domaine de Marcenat, 15190 Marcenat, France

(Received 11 April 2005 - Accepted 22 December 2005)

\begin{abstract}
This paper analyses the consequences of repeated regrouping of dairy heifers according to their behaviour, stress physiology and production. Thirty-two Holstein heifers were housed in pairs. Between 11 and 13 months of age, half were subjected to 16 pen relocations each time with a new peer (regrouped heifers), while the other half remained in the same pen with the same peer (controls). The heifers were observed in standardised behavioural tests comprising sudden (opening of an umbrella), novel (an unfamiliar arena) or predator-related (dog) stimuli. All behavioural tests were conducted on three sessions between the 13th and the 16th regroupings. The functioning of the HPA axis was assessed through blockade by dexamethasone and stimulation by ACTH after the 14 th regrouping and stimulation by CRF after the 15 th regrouping. Weight gain was assessed during the regrouping period and reproduction (No. of inseminations before successful insemination) thereafter. Regrouped heifers reacted less than the controls to the umbrella $\left(\chi^{2}=8.23, P<0.05\right)$. They started eating more quickly in the arena $(\mathrm{F}=10.8, P<0.01)$. In the presence of the dog, they were less active $(\mathrm{F}=6.26, P<0.05)$ and tended to look at the dog less often $(\mathrm{F}=3.63, P<0.10)$. The reduction in behavioural responses from one session to the next one was more pronounced in regrouped heifers (e.g. number of eating bouts: $\mathrm{F}$ (session $\times$ treatment $)=4.23, P<0.05)$. Regrouped heifers had lower cortisol responses to CRF. In conclusion, repeatedly regrouped heifers appear less disturbed by unusual situations and habituate to those more quickly. According to the behaviour of heifers and as suggested by their lower cortisol responses, diversity rather than stability of the social environment appears more beneficial to them.
\end{abstract}

heifer / regrouping / behavioural reactivity / CRF-challenge / ACTH-challenge

Résumé - Des mélanges répétés d'animaux diminuent la réactivité comportementale de génisses pubères. Cet article rapporte les conséquences de mélanges répétés d'animaux sur le comportement, le stress et la production de génisses de race laitière. Trente deux génisses Holstein ont

\footnotetext{
*Corresponding author: satu.raussi@mtt.fi
} 
été élevées par paires. Au sein de huit paires, les animaux ont changé de partenaires une à deux fois par semaine entre 11 et 13 mois d'âge, pour un total de 16 mélanges (génisses " mélangées "). Ces mélanges s'accompagnaient également de changements de parc. Les huit autres paires sont restées inchangées (génisses " témoins "). La réactivité comportementale a été mesurée en exposant les génisses à un événement soudain (ouverture d'un parapluie), à un environnement nouveau (alimentation dans un nouvel enclos) et à un prédateur (chien). Chaque test était répété trois fois, entre le $13^{\mathrm{e}}$ et le $16^{\mathrm{e}}$ mélange. Le fonctionnement de l'axe corticotrope a été évalué à l'aide d'un test de freination par la dexamethasone puis stimulation par l'ACTH après le $14^{\mathrm{e}}$ mélange et par un test de stimulation au CRF après le $15^{\mathrm{e}}$ mélange. Le gain de poids a été évalué par pesée hebdomadaire au cours des 16 mélanges. Par la suite, le nombre d'inséminations avant insémination fécondante a été relevé. Les génisses mélangées ont réagi à l'ouverture du parapluie moins fortement que les témoins $\left(\chi^{2}=8,23, P<0,05\right)$. Elles ont commencé à manger plus rapidement dans l'enclos nouveau $(\mathrm{F}=$ $10,8, P<0,01)$. En présence du chien, elles ont été moins actives $(\mathrm{F}=6,26, P<0,05)$ et tendaient à le regarder moins souvent $(\mathrm{F}=3,63, P<0,10)$. En outre, la diminution des réponses comportementales d'une séance sur l'autre était plus marquée chez les génisses mélangées (par exemple, nombre de prises alimentaires : $\mathrm{F}$ (séance $\times$ traitement) $=4,23, P<0,05$ ). Par ailleurs, l'élévation du taux plasmatique de cortisol consécutive à l'injection de CRF a été moins prononcée chez les génisses mélangées. En conclusion, les génisses préalablement exposées à des réallotements répétés sont moins perturbées par des situations non familières et s'y habituent plus facilement par comparaison aux génisses maintenues avec le même partenaire. Dans ces conditions, il semblerait que ce soit la diversité de l'environnement social plutôt que sa stabilité qui ait permis d'améliorer la réactivité émotionnelle des génisses.

génisses / mélange d'animaux / réactivité comportementale / réactivité surrénalienne

\section{INTRODUCTION}

It is often argued that farm animals should be housed in stable social environments. The Pig Welfare Advisory Group [13] advises avoiding the re-mixing of sows, and the Council of Europe [11] recommends that "bulls should not be added to groups already formed". Reorganisation of social groups induces stressrelated behavioural and physiological reactions [1, 20]. Mixing dairy cows results in short lying bouts, prolonged standing, reduced time spent eating and decreased milk production $[18,27]$. In pigs, fighting and stress responses following mixing, especially during the embryo implantation period, can affect reproduction [2].

The effects of regrouping on behaviour are generally short. In female cattle, fights between new animals are limited to the first hours after regrouping. Thereafter, relationships are maintained by threats from the dominant animal and spontaneous avoidance by the subordinate animal [5]. However, the milk yield of mixed cows re- mains lower than that of unmixed cows for 1 or 2 weeks after mixing $[18,27]$.

Nevertheless, grouping or other social stressors affect the activity of the hypothalamic-pituitary-adrenal (HPA) axis for a prolonged period. Chronic stress modifies the functioning of the HPA axis and modifications can result in hyper- or hypoactivity of the axis or disruptions in its activity [38]. The functioning of the HPA axis is generally assessed through its activation after the administration of the corticotropic-releasing factor (CRF) or the adenocorticotropic hormone (ACTH), and its blockade after the administration of a glucocorticoid, generally dexamethasone. Ladewig and Smidt [19] found that the sensitivity of bulls' adrenals to ACTH is decreased after five weeks of tethering. However, most studies suggest that prolonged or repeated aversive situations induce a hypersensitivity of the adrenals of cattle. Tethered calves or bulls deprived of lying down have increased cortisol responses following the administration of 
ACTH $[12,16,25]$. Similarly, social stressors like mixing or free stall competition increase the cows' cortisol response to ACTH [17, 18]. Moreover, when mixing is repeated, although calves' behavioural reactions to new partners seem to fade, the adrenals still become hypersensitive to ACTH [46]. It is generally accepted that chronic stress induces a hypersensitivity of adrenals to ACTH, a lower sensitivity of the pituitary to CRF and a lower suppression after dexamethasone administration [22]. Therefore, according to its prolonged effects on the HPA axis activity, especially on the sensitivity of adrenals to ACTH, social stressors are likely to induce a chronic stress state.

There is evidence that chronic stress induced by social instability or isolation alters the reactivity of animals to unexpected events. Deprivation of lying down and social isolation change the cows reactions to a novel environment [24]. Tethered sows react less to external events [9], while isolation or repeated mixing leads to higher reactivity in calves $[4,43]$. Chronic stress also induces immune dysregulation, which, in turn can have health implications [26]. In addition, repeated stressors can alter the growth of animals, as seen in rats reared in unstable social environments [23].

Regrouping might have greater effects on subadult or adult animals than on young animals because social behaviour develops with age; aggressions are more marked and animals mixed at a later stage accept each other less easily [7]. We have previously detected that heifers do not habituate to repeated mixing as seen through the more and more frequent agonistic interactions when regrouping is repeated several times [29] whereas very few interactions have been observed between newly mixed calves [46]. Due to this lack of behavioural habituation, regrouping may affect the heifers' emotional reactivity, phys- iology and production to a greater extent than it does in calves.

The aim of the experiment reported here was to investigate how repeated regrouping affects the welfare of heifers. According to the rationale developed by Désiré et al. [14], the behavioural reactivity of animals was tested in relation to sudden events, to unfamiliar ones and to a potential predator. Physiological responses were assessed through the functioning of the HPA axis (CRF and dexamethasone/ACTH challenges). In addition, the effects of regrouping on heifers' growth and reproduction were noted. This paper offers the possibility to compare the effect of social stressors between animals with a fully developed social behaviour (i.e. heifers after puberty) and the results obtained on young animals (i.e. calves) with immature social behaviour and greater tolerance to each other as observed previously by Boissy et al. [4] and Vessier et al. [46].

\section{MATERIALS AND METHODS}

The experiment was carried out at the experimental farm of INRA at Marcenat (Cantal, France). The scientists responsible for the experiment (Veissier and Boissy in France and Raussi in Finland) are licensed to perform experiments on animals according to French and Finnish regulations. People in charge of rearing the animals or taking samples from them completed a course on experimental animals approved by the French Ministry of Agriculture.

\subsection{Animals, housing and experimental treatments}

The animals, housing and experimental treatments are the same as reported by Raussi et al. [29]. Briefly, thirty-two female Holstein-Friesian calves born in October 2000 were housed in pairs in $1.8 \times$ 
$2 \mathrm{~m}$ pens separated by solid wooden partitions. They were fed milk replacer and hay, and weaned from milk at 12 weeks of age.

At six months of age and weight of $221 \mathrm{~kg}( \pm 6)$, each pair of animals (called heifers from that time) was moved to a $4 \times$ $5 \mathrm{~m}$ pen, with each pen separated from the others by solid wooden partitions, $2 \mathrm{~m}$ high. The animals were fed hay and concentrate in the morning (respectively $10 \mathrm{~kg}$ and $2.5 \mathrm{~kg}$ per day per animal). Water was always available ad libitum.

Eight pairs of heifers were kept in the same pens until 13 months of age (controls). For the remaining eight pairs, the pens and penmates of the heifers were changed repeatedly (regrouped heifers). From the age of 11 months, the heifers were weighed twice a week for five weeks, then once a week for six weeks, that is in total 16 times (Tab. I). Each heifer was taken individually out of its pen for weighing, after which any control heifer was returned to its own pen, while any regrouped heifer was put into a different pen together with an unfamiliar heifer from the same treatment. At 13 months of age, the heifers were integrated into the farm's main heifer herd. Twenty-two heifers (eleven per treatment) were to be inseminated right after. If not in heat within 50 days after integration, they received a hormonal treatment to induce heat: intramuscular (IM) injection of $3 \mathrm{mg}$ Norgestomet (17alphaacetoxy -11 beta-methyl-19-norpreg - 4-en3.20 dione) and $3.8 \mathrm{mg}$ oestradiol, ear implant of $3 \mathrm{mg}$ Norgestomet for 10 days, IM injection of $15 \mathrm{mg}$ Luprostiol (prostaglandin F2 $\alpha$ analogue) two days before implant removal and 400 IU gonadotrophin at removal, insemination two days later. The remaining heifers were to be inseminated the next year. Throughout the experiment, stockpersons checked the health of the animals twice daily and medical treatment was given when necessary.
Table I. Calendar of the treatments and measurements performed on the heifers.

\begin{tabular}{|c|c|}
\hline Day & Treatment/Measurement \\
\hline 19.10 .2001 & Weighing and regrouping 1 \\
\hline 23.10 .2001 & Weighing and regrouping 2 \\
\hline 26.10.2001 & Weighing and regrouping 3 \\
\hline 29.10.2001 & Weighing and regrouping 4 \\
\hline 02.11 .2001 & Weighing and regrouping 5 \\
\hline 06.11 .2001 & Weighing and regrouping 6 \\
\hline 09.11 .2001 & Weighing and regrouping 7 \\
\hline 13.11.2001 & Weighing and regrouping 8 \\
\hline 16.11.2001 & Weighing and regrouping 9 \\
\hline 20.11.2001 & Weighing and regrouping 10 \\
\hline 23.11.2001 & Weighing and regrouping 11 \\
\hline 27.11.2001 & Weighing and regrouping 12 \\
\hline 30.11 .2001 & Weighing and regrouping 13 \\
\hline 04.12 .2001 & Umbrella test 1 \\
\hline 05.12 .2001 & Umbrella test 2 \\
\hline 06.12 .2001 & Umbrella test 3 \\
\hline 07.12 .2001 & Weighing and regrouping 14 \\
\hline 11.12.2001 & Novel arena test 1 \\
\hline 12.12.2001 & Novel arena test 2 \\
\hline 13.12.2001 & $\begin{array}{l}\text { Novel arena test } 3 \text {, } \\
\text { Dexamethasone injection }\end{array}$ \\
\hline 14.12 .2001 & $\begin{array}{l}\text { ACTH challenge test, } \\
\text { weighing and regrouping } 15\end{array}$ \\
\hline 17.12.2001 & Dog test 1 \\
\hline 18.12.2001 & Dog test 2 \\
\hline 19.12.2001 & Dog test 3 \\
\hline 21.12.2001 & $\begin{array}{l}\text { CRF challenge test, } \\
\text { weighing and regrouping } 16\end{array}$ \\
\hline
\end{tabular}

\subsection{Behavioural tests}

A calendar of the behavioural tests together with physiological challenges and weighing/regrouping treatment is reported in Table I.

\subsubsection{Umbrella test}

An umbrella test, adapted from Boissy et al. [4], was run between 09:00 and $11: 00 \mathrm{~h}$, from the fourth day after the $13 \mathrm{th}$ 


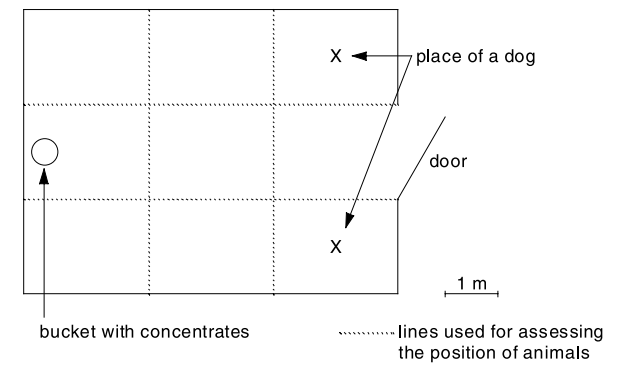

Figure 1. Arena used for the arena and the dog tests.

regrouping. It was conducted on three consecutive daily sessions. The heifers were not given their daily portion of concentrates on the test morning. Plywood partitions were placed in front of all pens to prevent the heifers from seeing the tests run on adjacent pens. A closed umbrella, which could be opened from a remote place, was placed in front of the pen, $1.2 \mathrm{~m}$ from the feeding trough. The plywood partition was removed and $30 \mathrm{~s}$ later the daily portion of concentrate was put in the trough. After the heifers had eaten concentrate for $10 \mathrm{~s}$, the umbrella was opened. Two observers stood to the side of the pen, $2 \mathrm{~m}$ from the trough, in sight of the heifers. For each heifer, they recorded the latency to start eating, the reaction to the opening of the umbrella (on a $0-3$ scale with $0=$ no reaction, $1=$ heifer stops eating but does not move back, 2 = heifer takes one step back and $3=$ heifer takes several steps back), and the latency to resume eating after the umbrella was opened (truncated at $90 \mathrm{~s}$ ).

\subsubsection{Arena test}

The heifers were individually exposed to an arena test that was conducted on three consecutive daily sessions from the fourth day after the 14th regrouping. The arena was unknown to the animals before the first test. It was $5.4 \times 7.1 \mathrm{~m}$, with an earthen floor and wooden walls $2.2 \mathrm{~m}$ high (Fig. 1). A video camera was fixed above the arena and connected to a monitor placed outside the arena. A bucket filled with half of a heifer's daily portion of concentrates was placed in the middle of the arena wall opposite to the door. The arena floor was divided into nine rectangles marked on the monitor screen.

Half of the animals were tested between 08:45 and 12:00 $\mathrm{h}$ and half between 13:45 and 17:00 $\mathrm{h}$. The animals tested in the morning did not receive their normal portion of concentrate that morning, but were given half a portion at 12:00 h. The animals tested in the afternoon received only half of their normal portion of concentrate in the morning. Each animal to be tested was taken out of its pen, led to the arena and left there alone for $8 \mathrm{~min}$. After $8 \mathrm{~min}$, the door was opened and the animal was allowed $30 \mathrm{~s}$ to leave the arena. If it did not leave the arena within $30 \mathrm{~s}$, it was gently pushed out. Then it was led back to its pen. The floor of the arena was cleaned of urine and faeces after every test.

The animals were observed from the monitor screen. The behaviour was encoded on a hand-held computer (Psion Workabout) using the Observer Program (Noldus, the Netherlands). Two classes of behavioural states were considered: position and activity. The position corresponded to the rectangle where the animal had its forelegs. The activities included the following: sniffing the arena (the animal stretched its neck and its nose was less than $10 \mathrm{~cm}$ from the floor, a wall or the door), eating, other activity and no activity. In addition, low vocalisations (mooing with mouth closed), high vocalisations (mooing with mouth open) and defecations were considered events. The time taken to leave the arena was also recorded. The latency and frequency of any behaviour and the duration of behavioural states were further calculated using the Observer software. The total frequency of entering any rectangle was taken as a comprehensive score of movements in the arena. 


\subsubsection{Dog test}

The heifers were individually exposed to a dog test that was conducted on three daily sessions from the third day after the 15 th regrouping, using the same procedure as Boissy et al. [4]. It was performed in the same arena used for the arena tests (see above). A Border collie shepherd and its master participated in the test. In between the tests, the dog stayed outside the arena, out of sight of the heifers. The same general procedure as for the arena test was followed. After the heifer had continuously eaten concentrate in the arena for $15 \mathrm{~s}$, the dog was commanded to go into the arena through a narrow slot in the wall and to sit down to the right of the arena door. After one minute, the dog was commanded to go and sit down to the left of the door. This procedure was conducted once. Then the dog was commanded to leave the arena through the slot. As soon as the dog was out of the arena, the door was opened. The behaviour of the heifer was recorded for the time the dog was in the arena. This time varied from 200 to $300 \mathrm{~s}$ except $132 \mathrm{~s}$ for one heifer that butted the dog. The same behavioural states and events as for the arena test were recorded. The following behavioural states were added: looking at, sniffing and licking the dog; eating concentrates without looking at the dog (that is with an angle between the heifer's body and the nearest wall equal to or greater than $45^{\circ}$ ) and eating concentrates while looking at the dog (angle between the body and the nearest wall less than $45^{\circ}$ ). Any threats (same movement as a butt but without touching the dog) towards the dog were also noted.

\subsection{CRF and Dexamethasone/ACTH challenges}

The heifers were accustomed to being tethered for two hours per day during four days between the 12th and 13th regroupings. The procedures of the CRF and
Dexamethasone/ACTH challenge tests followed those proposed by Veissier and Le Neindre [40] and Veissier et al. [45].

Dexamethasone suppresses endogenous cortisol secretion so that an animal has a low level of cortisol at the time of ACTH injection [40]. The Dexamethasone/ACTH challenge was performed on all the heifers on the 6 th and 7 th days after the 14th regrouping following the procedure developed by Veissier and Le Neindre [40]. A dose of $20 \mu \mathrm{g}$ per $\mathrm{kg}$ BW dexamethasone (Dectancyl $^{\text {ND }}$, Roussel, Paris, France) was injected IM between 17:00 and 18:00 h. The next morning, from 08:00 to $12: 00 \mathrm{~h}$, the heifers were tethered before they were intravenously (IV) injected with 1 IU per kg BW ACTH (Synacthene ${ }^{\mathrm{ND}}$, Novartis Pharma, Rueil Malmaison, France). Blood samples were taken by jugular venepuncture immediately before the injection of dexamethasone and before and 30, 120 and 180 min after ACTH injection.

The CRF challenge was run on the 7th day after the 15 th regrouping, between 09:00 and 12:00 h, on one heifer randomly chosen from each pair, according to a procedure developed by Veissier et al. [45]. The two heifers of a pen were tethered before one was IV injected with $1 \mu \mathrm{g}$ per $\mathrm{kg}$ BW bovine CRF (Sigma-Aldrich, Saint Quentin-Fallavier, France). Blood samples were taken by jungular venepuncture immediately before the injection and 20, 60 and $90 \mathrm{~min}$ after the injection.

Blood samples were centrifuged immediately and the plasma was stored at $-20^{\circ} \mathrm{C}$ for $24 \mathrm{~h}$ and thereafter at $-80{ }^{\circ} \mathrm{C}$. Plasma ACTH concentrations were determined by radioimmunoassay (RIA, Nichols Institute of Diagnostics, San Juan Capistrano, CA). The detection limit was $1 \mathrm{pg}$ per $\mathrm{mL}$, and the coefficients of variation within and between assays were 2.6 and $8.3 \%$ for low (16 pg per $\mathrm{mL}$ ) and 4 and 6\% for high (300 pg per $\mathrm{mL}$ ) controls, respectively. Plasma levels of cortisol were determined by RIA, with an antibody produced by Cognié and 
Poulin (INRA, Tours). The detection limit was $0.02 \mathrm{ng}$ per $\mathrm{mL}$, and the coefficients of variation within and between assays were 11 and $22 \%$ for low (4 ng per $\mathrm{mL}$ ) and 7 and $14 \%$ for high ( $32 \mathrm{ng}$ per $\mathrm{mL}$ ) controls, respectively. The integrated responses to ACTH and to CRF were calculated as the area under the curves (AUC) using the following equation:

$$
\sum_{\mathrm{t}=1}^{\mathrm{N}-1} 1 / 2\left(\mathrm{C}_{\mathrm{t}}+\mathrm{C}_{\mathrm{t}+1}\right) \Delta \mathrm{t}
$$

where $\mathrm{N}$ is the total number of blood samples, $\mathrm{C}$ is the concentration of ACTH or of cortisol and $\Delta \mathrm{t}$ is the time interval between successive samples. In the Dexamethasone/ACTH test, the cortisol AUC was based on a baseline taken from the pre ACTH samples.

\subsection{Production and health}

Body weight gains were calculated from all weighings performed from the 1 st to the 16 th regrouping. The frequency of health problems and the number of days on which an animal received a medical treatment were noted from birth until the heifers' integration into the main herd at 13 months of age. The number of heifers in heat within 50 days after integration into the herd and the times of first insemination and successful insemination were recorded for the 22 heifers to be inseminated right after the end of the regrouping procedure.

\subsection{Statistics}

The SAS statistical package [33] was used to run all statistical analyses. Variance analyses were performed for all continuous data. The hypotheses of a normal distribution and homogeneous variances were checked on the residuals. Because the umbrella test was conducted on pairs, the pair of heifers was considered as the observation unit. The mean values from the pairs of heifers were calculated and variance analyses were run on these means with a model including the effects of treatment (regrouped vs. control), the pair of animals (random factor nested in treatment) and the interaction between the treatment and the session (1,2 or 3$)$. A similar model was used for data from the arena and dog tests, except that the individual animal was taken as a random factor and not the pair because animals were tested alone. In the dog test, the time spent by the dog in the arena was added as a covariate. For the other continuous data (response to dexamethasone, ACTH or CRF, daily weight gain and time of heat or insemination), only treatment effects were considered. Post hoc comparisons were performed with the 'least squares mean' procedure. Chi-squares were calculated to compare the proportions.

The results are expressed as means \pm standard errors. The results section will focus on significant results $(P<0.05)$ and tendencies $(P<0.10)$. Although significant effects of the session number were observed in behavioural tests, they are not commented unless they interacted with the treatments.

\section{RESULTS}

\subsection{Behavioural tests}

\subsubsection{Umbrella test}

During the umbrella tests the regrouped heifers tended to start eating in front of the closed umbrella more quickly than the controls (3.23 vs. $3.80 \mathrm{~s}, \mathrm{SE}=0.31, \mathrm{~F}=3.40$, $P=0.09$ ). They had milder reactions to the opening of the umbrella (reaction 0: 22 vs. 16 heifers, reaction 1: 12 vs. 10 , reaction 2: 10 vs. 10 , and reaction $3: 2$ vs. $12, \chi^{2}=$ $8.23, P<0.05)$.

\subsubsection{Arena test}

The results of the arena test are summarised in Table II for comparisons 
Table II. The results from the three arena tests of 16 regrouped (16 changes of partner and of pen) and 16 control heifers (maintained in stable pairs and in the same pen).

\begin{tabular}{lccccc}
\hline & \multicolumn{2}{c}{ Mean } & SE & F & $P$ \\
\cline { 2 - 3 } & Regrouped & Control & & & \\
\hline Frequency of entering a rectangle & 35.9 & 33.5 & 5.14 & 0.17 & 0.68 \\
Time spent next to the bucket (s)* & 362 & 354 & 19.1 & 0.14 & 0.71 \\
Time spent next to the door (s)* & 25.4 & 27.6 & 5.34 & 0.13 & 0.72 \\
Time spent sniffing the arena (s) & 67.7 & 72.4 & 7.47 & 0.33 & 0.57 \\
Frequency of low vocalisations & 3.52 & 3.54 & 0.91 & 0.00 & 0.98 \\
Frequency of high vocalisations & 2.13 & 1.69 & 0.63 & 0.38 & 0.54 \\
Frequency of defecations & 0.15 & 0.27 & 0.09 & 1.66 & 0.21 \\
Latency to eat (s) & 8.84 & 26.9 & 4.90 & 10.8 & $<0.01$ \\
Number of eating bouts & 10.7 & 11.1 & 1.31 & 0.10 & 0.76 \\
Time spent eating (s) & 295 & 277 & 21.6 & 0.55 & 0.46 \\
Latency to go out of the arena (s) & 13.4 & 27.1 & 3.87 & 9.93 & $<0.01$ \\
\hline
\end{tabular}

* In the rectangle with the bucket or door, respectively.

between treatments. F and $P$ values for the interaction between treatment and session are given in the text.

The regrouped heifers started eating more quickly than the controls, with this being more marked in Session 1 (F (treatment $\times$ session $)=8.71, P<0.001)$. They also had more eating bouts in Session 1 than in subsequent sessions (number of bouts of eating: 13.2 in Session 1 vs. 9.4 in Sessions 2 and 3 ), whereas the controls had the same numbers of eating bouts (11.1) over the sessions. The regrouped heifers had more eating bouts than did the controls in Session 1, but fewer bouts in Session $2(\mathrm{~F}$ (treatment $\times$ session $)=4.23$, $P<0.05)$. The regrouped heifers went out of the arena more quickly than the controls.

\subsubsection{Dog test}

The results of the dog test are summarised in Table III for comparisons between treatments. The $\mathrm{F}$ and $P$ values for the interaction between treatment and session are given in the text.

The regrouped heifers moved around the arena less than the controls. They also tended to spend more time near the bucket, more time eating without looking at the dog and less time near the door, and to have low vocalisations less often. They tended to look at the dog later, less frequently and for a shorter time. The frequency of threats to the dog decreased between Session 1 and later sessions in the regrouped heifers and between Sessions 2 and 3 in the controls; the regrouped animals threatened the dog more often than did the controls in Session 1 (0.31 vs. 0.06), whereas the opposite was true in Session 2 (0 vs. $0.25)$, and threats were absent in Session 3 $(\mathrm{F}($ treatment $\times$ session $)=4.05, P<0.05)$.

\subsection{CRF and Dexamethasone/ACTH challenges}

During the dexamethasone/ACTH challenge, similar cortisol responses to the administration of dexamethasone or ACTH were observed in both treatments (Tab. IV). In the $\mathrm{CRF}$ challenge, the regrouped heifers had ACTH responses similar to those of the controls, but lower cortisol responses. 
Table III. The results from the three dog tests of 16 regrouped (16 changes of partner and of pen) and 16 control heifers (maintained in stable pairs and in the same pen).

\begin{tabular}{lccccc}
\hline & \multicolumn{2}{c}{ Mean } & SE & F & $P$ \\
\cline { 2 - 3 } & Regrouped & Control & & & \\
\hline Frequency of entering a rectangle & 7.52 & 13.3 & 2.06 & 6.26 & $<0.05$ \\
Time spent next to the bucket (s)* & 218 & 192 & 12.8 & 3.41 & 0.07 \\
Time spent next to the door (s)* & 7.49 & 15.4 & 4.06 & 3.14 & 0.09 \\
Time spent next to the dog (s)* & 6.35 & 11.0 & 2.98 & 1.95 & 0.17 \\
Time spent sniffing the arena (s) & 6.35 & 7.42 & 1.78 & 0.29 & 0.59 \\
Frequency of low vocalisations & 0.02 & 0.21 & 0.09 & 3.30 & 0.08 \\
Frequency of high vocalisations & 0.00 & 0.02 & 0.02 & 0.96 & 0.33 \\
Latency to eat with dog (s) & 5.84 & 9.23 & 4.88 & 0.39 & 0.54 \\
Number of eating bouts & 6.81 & 6.96 & 0.74 & 0.03 & 0.86 \\
Time spent eating (s) & & & & & \\
$\quad$ while looking at the dog & 102 & 109 & 16.5 & 0.16 & 0.69 \\
$\quad$ while not looking at the dog & 75.1 & 37.5 & 17.2 & 3.83 & 0.06 \\
Latency to look at the dog (s) & 25.2 & 8.92 & 8.09 & 3.32 & 0.08 \\
Frequency of looking at the dog & 7.33 & 9.54 & 1.04 & 3.63 & 0.07 \\
Time spent looking at the dog (s) & 34.6 & 48.0 & 7.03 & 2.90 & 0.10 \\
Latency to sniff the dog (s) & 163 & 137 & 23.5 & 1.03 & 0.32 \\
Frequency of sniffing the dog & 1.92 & 1.81 & 0.48 & 0.04 & 0.85 \\
Time spent sniffing the dog (s) & 12.6 & 12.0 & 3.45 & 0.02 & 0.88 \\
Frequency of threatening the dog & 0.10 & 0.10 & 0.06 & 0.00 & 0.99 \\
Latency to go out of the arena (s) & 10.4 & 9.56 & 1.93 & 0.15 & 0.70 \\
\hline
\end{tabular}

* In the rectangle(s) with the bucket, the door or the dog, respectively.

\subsection{Production and health}

No differences between treatments were observed in growth or reproduction (Tab. IV). No statistics were compiled on the health of the heifers since only one regrouped heifer had lameness during the experiment.

\section{DISCUSSION}

Heifers that had been repeatedly regrouped reacted less than undisturbed controls during the behavioural tests. They had milder responses to the sudden opening of the umbrella, started eating more quickly in the arena and tended to eat for longer without looking at the dog in the dog test. They also had lower cortisol responses to exogenous CRF. Repeated regrouping did not affect the growth or reproduction of the heifers.

The fearfulness of animals is often characterised in situations that are either sudden or novel, or that include cues from predators [3]. Because repeatedly regrouped heifers were less reactive in sudden (umbrella) and in novel situations (arena) and in the presence of a dog, it is likely that repeated regrouping reduces the fear reactions of heifers.

The regrouped heifers tended to display less activity towards the dog than the controls (they tended to be slower to look at the dog and tended to look at it less often and 
Table IV. The results from CRF and ACTH challenges and production data from 16 regrouped (16 changes of partner and pen) and 16 control heifers (maintained in stable pairs and in the same pen).

\begin{tabular}{|c|c|c|c|c|c|}
\hline & \multicolumn{2}{|c|}{ Mean } & \multirow[t]{2}{*}{ SE } & \multirow[t]{2}{*}{$\mathrm{F} / \mathrm{X}^{2}$} & \multirow[t]{2}{*}{$P$} \\
\hline & Regrouped & Control & & & \\
\hline Dexamethasone/ACTH challenge & $\mathrm{n}=16$ & $\mathrm{n}=16$ & & & \\
\hline Plasma cortisol before dexamethasone $\left(\mathrm{ng} \cdot \mathrm{mL}^{-1}\right)$ & 2.88 & 4.03 & 0.50 & 1.41 & 0.25 \\
\hline Plasma cortisol after dexamethasone $\left(\mathrm{ng} \cdot \mathrm{mL}^{-1}\right)^{1}$ & 0.67 & 0.78 & 0.12 & 0.23 & 0.64 \\
\hline $\mathrm{AUC}^{2}$ of cortisol $\left(\mathrm{ng} \times \mathrm{min} \cdot \mathrm{mL}^{-1}\right)$ & 8255 & 8608 & 254 & 0.52 & 0.48 \\
\hline CRF challenge & $\mathrm{n}=8$ & $\mathrm{n}=8$ & & & \\
\hline AUC of cortisol $\left(\mathrm{ng} \times \min \cdot \mathrm{mL}^{-1}\right)$ & 1637 & 2344 & 170 & 4.96 & $<0.05$ \\
\hline AUC of ACTH $\left(\mathrm{pg} \times \mathrm{min} \cdot \mathrm{mL}^{-1}\right)$ & 10076 & 11355 & 1322 & 0.27 & 0.61 \\
\hline Growth & $\mathrm{n}=16$ & $\mathrm{n}=16$ & & & \\
\hline Daily weight gain $\left(\mathrm{g} \cdot \mathrm{day}^{-1}\right)^{3}$ & 699 & 645 & 26.2 & 1.15 & 0.29 \\
\hline Reproduction & $\mathrm{n}=11$ & $\mathrm{n}=11$ & & & \\
\hline Days before first insemination ${ }^{4}$ & 20.8 & 29.1 & 4.17 & 1.08 & 0.31 \\
\hline Days before successful insemination ${ }^{4}$ & 292 & 119 & 85.5 & 1.13 & 0.30 \\
\hline Number of heifers in heat within 50 days 4,5 & 8 & 7 & & 0.21 & 0.65 \\
\hline $\begin{array}{l}1 \text { Blood samples taken } 15 \mathrm{~h} \text { after IM dexamethason } \\
2 \text { Area under the curve. } \\
{ }^{3} \text { Calculated from } 11 \text { to } 14 \text { months of age. } \\
4 \text { Calculated from } 14 \text { months of age. } \\
5 \text { Fisher exact probabilities. }\end{array}$ & ection. & & & & \\
\hline
\end{tabular}

more briefly) and more towards the food (they tended to spend more time near the bucket and more time eating without looking at the dog). In addition, the changes in behaviour over the sessions were more marked in the regrouped heifers than in the controls. A decrease in the frequency of threats to the dog was observed after the first session in the regrouped heifers but only after the second session in the controls. A similar tendency was observed in the arena test in the absence of the dog; the frequency of eating bouts decreased more rapidly in the regrouped heifers than in the controls. More rapid changes over time could explain why the regrouped heifers were less active and more focussed on the food than the controls in the dog test. These results suggest that habituation processes occur more rapidly in heifers repeatedly regrouped than in heifers kept in stable pairs.

Studies on rats and hamsters showed that animals reared in a restricted and small environment are less able to use environmental cues than animals reared in larger or more complex environments (Brown [10]; Thinus-Blanc [36, 37]). These findings were confirmed by the results of Varty et al. [39], who found that rats reared in an enriched environment acquire information from their environment more easily than rats reared in isolation. Similarly, pigs housed in an enriched environment learn an operant task better than those housed in a poor environment [34]. Enriching an animal's environment can thus improve its learning abilities. Since cattle are gregarious species that generally 
live in large groups, housing our control heifers by pair with no contact with other animals may have formed a stimulus poor environment for them. In such circumstances, maintaining the same penmate all the time probably was perceived as a constraint by our control heifers, which could impair their subsequent ability to habituate to the procedures during the behavioural tests. In such a case, repeated regroupings and the subsequent increase of social interactions (although agonistic) can have alleviated the negative effect, due to the low level of social experiences, that living with the same penmate (i.e. in stable pair) could not have compensated.

The heifers that had stayed in stable pairs had higher cortisol responses to an injection of exogenous CRF than the heifers that had been repeatedly regrouped, but their ACTH responses were similar. Most studies report an increase in adrenal response to ACTH challenge in loosehoused female cattle in response to longterm stressors [15-17] rather than a decrease [30]. We cannot, however, offer any firm conclusions on whether our heifers experienced chronic stress. To confirm such a hypothesis, one would need to compare acute responses (i.e. the release of cortisol right after each regrouping) with longterm responses (i.e. changes in functioning of the HPA axis). This was not investigated in the present work. Thus, we can only conclude that a decrease in adrenal sensitivity to ACTH occurred in heifers submitted to repeated regrouping.

The results that we obtained for heifers are the contrary to previous observations on calves. Using similar tests, Boissy et al. [4] found that calves undergoing repeated regroupings are more sensitive to novel aspects of their environment. Such calves also have enhanced cortisol responses to ACTH [46]. However, in these studies on calves as well as in our work on heifers, behavioural reactivity and physiological modifications vary together: the higher the behavioural reactivity of animals, the more sensitive their adrenals to ACTH. Thus, animals that are more readily afraid are likely to present signs of enhanced reactivity of the adrenals to ACTH.

Animals at different ages, e.g. calves and heifers, have different social motivations and needs [44]. A stable social environment and bonding with the dam are important for calves [41]. Rearing calves in individual crates has, however, no long-lasting effects on their social behaviour [42]. The situation might be different at puberty. Bouissou and Andrieu [8] found that the social behaviour of heifers develops at puberty. Socially experienced heifers fight less and establish their dominance relations more rapidly than socially inexperienced heifers [6]. The importance of a diverse social environment at puberty for later socialisation of animals has been reported in guinea pigs by Sachser [31] and Sachser et al. [32]. Social skills of gilts are also improved by regrouping [28]. Because our heifers had all reached puberty before the start of the regrouping treatments, they might have been in a critical period of social development, whereas the calves observed by Boissy et al. [4] and Veissier et al. [46] had not yet reached this stage.

We observed no significant difference between regrouped and control heifers in growth or immediate reproductive success. Our treatments were probably not severe enough to affect the growth or reproduction of heifers. In addition, concerning reproductive success, too few animals were observed to be able to detect an effect. While responses in behaviour and adrenal activity were detected in repeatedly regrouped calves $[4,46]$, no differences were seen in body weight gain. Hence, in cattle, behavioural and physiological modifications seem to be more sensitive indicators of welfare than productivity, a phenomenon that has also been observed in pigs by Meunier-Salaun et al. [21]. 
In our study with heifers, the smallest possible group, a pair, was used. Our regrouped heifers may have felt like they were housed in a larger group, although they met only one new penmate at a time. This assumption would be consistent with the conclusions of Takeda et al. [35] that the heifers' emotional responses to novelty and surprise are lower in groups of five than in groups of two.

In conclusion, although repeated regrouping causes more agonistic interactions among heifers and increases the distance kept between animals [29], it lowers the heifers' emotional reactivity to unusual events and is accompanied by signs of lower sensitivity of the adrenals to ACTH in comparison with rearing heifers in stable pairs. While lower reactivity might be undesirable for fitness of prey animals in the wild, it may constitute an advantage for production animals, not subjected to predators. In our study, the effects of repeated changes of partners and pens were confounded. Social skills of heifers are likely developed around puberty. Hence, social aspects were probably superior to pen changes. Diversity rather than stability of the social environment thus appears to be more beneficial to heifers in modern dairy husbandry, particularly when the rearing group has previously been small.

\section{ACKNOWLEDGEMENTS}

We are grateful to the INRA Marcenat staff for rearing the calves and heifers and for their active participation in the behavioural and physiological tests. INRA, the Finnish Ministry of Agriculture and Forestry, and the EU Commission (COST Action 846) gave financial support to the study.

\section{REFERENCES}

[1] Arave C.W., Albright J.L., Social Rank and Physiological Traits of Dairy Cows as
Influenced by Changing Group Membership, J. Dairy Sci. 59 (1976) 974-981.

[2] Arey D.S., Edwards S.A., Factors influencing aggression between sows after mixing and the consequences for welfare and production. A review, Livest. Prod. Sci. 56 (1998) 61-70.

[3] Boissy A., Fear and fearfulness in animals. A review, Q. Rev. Biol. 70 (1995) 165-191.

[4] Boissy A., Veissier I., Roussel S., Behavioural reactivity affected by chronic stress: an experimental approach in calves submitted to environmental instability, Anim. Welfare 10 (2001) 175-185.

[5] Bouissou M.F., Établissement des relations de dominance-soumission chez les bovins domestiques. I. Nature et évolution des interactions sociales, Ann. Biol. Anim. Bioch. Biophys. 14 (1974) 383-410.

[6] Bouissou M.F., Établissement des relations de dominance-soumission chez les bovins domestiques. III. Effet de l'expérience sociale, Z. Tierpsychol. 38 (1975) 419-435.

[7] Bouissou M.F., Étude du développement des relations de dominance-subordination chez les bovins, à l'aide d'épreuves de compétition alimentaire, Biol. Behav. 2 (1977) 213221.

[8] Bouissou M.F., Andrieu S., Établissement des relations de dominance-soumission chez les bovins domestiques. IV. Établissement des relations chez les jeunes, Biol. Behav. 2 (1977) 97-107.

[9] Broom D.M., Applications of neurobiological studies to farm animal welfare, in: Wiepkema P.R., Van Adrichem P.W.M. (Eds.), Biology of Stress in Farm Animals: An Integrative Approach, Martinus Nijhoff Publishers, Dordrecht, Boston, Lancaster, 1987, pp. 101-110.

[10] Brown R.T., Early experience and problemsolving ability, J. Comp. Physiol. Psychol. 65 (1968) 433-440.

[11] Council of Europe, Animal health and welfare. Animals kept for farming purposes. Recommendations adopted by the standing committee of the European Convention for the Protection of Animals Kept for Farming Purposes. Recommendations concerning cattle. Appendix A: Special provisions for bulls kept for breeding or fattening, 1988 [Online] 
Available: http://europa.eu.int/comm/food/ animal/welfare/farm/index_en.htm.

[12] Dantzer R., Mormède P., Bluthé R.M., Soissons J., The effect of different housing conditions on behavioural and adenocortical reactions in veal calves, Reprod. Nutr. Dév. 23 (1983) 501-508.

[13] DEFRA, Department for Environment Food and Rural Affairs, UK. Pig Welfare Advisory Group (PB3083). Introduction of Sows into Groups. Principal requirements to minimise aggression/ injury at mixing: Management [Online] Available: http://www.defra.gov.uk/animalh/welfare / farmed/pigs/index.htm.

[14] Désiré L., Boissy A., Veissier I., Emotions in farm animals: a new approach to animal welfare in applied ethology, Behav. Process. 60 (2002) 165-180.

[15] Fisher A.D., Verkerk G.A., Morrow C.J., Matthews L.R., The effects of feed restriction and lying deprivation on pituitaryadrenal axis regulation in lactating cows, Livest. Prod. Sci. 73 (2002) 255-263.

[16] Friend T.H., Polan C.E., Gwazdauskas F.C., Heald C.W., Adrenal Glucocorticoid Response to Exogenous Adrenocorticotropin Mediated by Density and Social Disruption in Lactating Cows, J. Dairy Sci. 60 (1977) 1958-1963.

[17] Friend T.H., Gwazdauskas F.C., Polan C.E., Change in Adrenal Response from Free Stall Competition, J. Dairy Sci. 62 (1979) $768-$ 771.

[18] Hasegawa N., Nishiwaki A., Sugawara K., Ito I., The effects of social exchange between two groups of lactating primiparous heifers on milk production, dominance order, behaviour and adrenocortical response, Appl. Anim. Behav. Sci. 51 (1997) 15-27.

[19] Ladewig J., Smitd D., Behaviour, Episodic Secretion of Cortisol, and Adrenocortical Reactivity in Bulls Subjected to Tethering, Horm. Behav. 23 (1989) 344-360.

[20] Mench J.A., Swanson J.C., Stricklin W.R., Social stress and dominance among group members after mixing beef cows, Can. J. Anim. Sci. 70 (1990) 345-354.

[21] Meunier-Salaun M.C., Vantrimponte M.N., Raab A., Dantzer R., Effect of floor area restriction upon performance, behaviour and physiology of growing-finishing pigs, J. Anim. Sci. 64 (1987) 1371-1377.
[22] Mormède P., Le stress : interaction animal-homme-environnement, Cah. Agric. 4 (1995) 275-286.

[23] Mormède P., Lemaire V., Castanon N., Dulluc J., Laval M., Le Moal M., Multiple neuroendocrine responses to chronic social stress: Interaction between individual characteristics and situational factors, Physiol. Behav. 47 (1990) 1099-1105.

[24] Munksgaard L., Simonsen H.B., Behavioural and Pituitary Adrenal-Axis Responses of Dairy Cows to Social Isolation and Depriovation of Lying Down, J. Anim. Sci. 74 (1996) 769-778.

[25] Munksgaard L., Ingvartsen K.L., Pedersen L.J., Nielsen V.K., Deprivation of Lying Down Affects Behaviour and PituitaryAdrenal Axis Responses in Young Bulls, Acta Agr. Scand. A. An. 49 (1999) 172-178.

[26] Padgett D.A., Glaser R., How stress influences the immune response, Trends Immunol. 24 (2003) 444-448.

[27] Phillips C.J.C., Rind M.I., The effects on production and behavior of mixing uniparous and multiparous cows, J. Dairy Sci. 84 (2001) 2424-2429.

[28] van Putten G., Buré R.G., Preparing gilts for group housing by increasing their social skills, Appl. Anim. Behav. Sci. 54 (1997) 173-183.

[29] Raussi S., Boissy A., Delval E., Pradel P., Kaihilahti J., Veissier I., Does repeated regrouping alter the social behaviour of heifers? Appl. Anim. Behav. Sci. 93 (2005) $1-12$.

[30] Roman-Ponce H., Thatcher W.W., Collier R.J., Wilcox C.J., Hormonal responses of lactating dairy cattle to TRH and ACTH in a shade management system within a subtropical environment, Theriogenology 16 (1981) 31-138.

[31] Sachser N., The ability to arrange with conspecifics depends on social experiences around puberty, Physiol. Behav. 53 (1993) 539-544.

[32] Sachser N., Dürschlag M., Hirzel D., Social relationships and the management of stress, Psychoneuroendocrinology 23 (1998) 891904.

[33] SAS, SAS Institute Inc., SAS OnlineDoc, Version 8, Cary, NC, 1999. 
[34] Sneddon I.A., Beattie V.E., Dunne L., Neil W., The effect of environmental enrichment on learning in pigs, Anim. Welfare 4 (2000) 373-383.

[35] Takeda K., Sato S., Sugawara K., Familiarity and group size affect emotional stress in Japanese Black heifers, Appl. Anim. Behav. Sci. 82 (2003) 1-11.

[36] Thinus-Blanc C., Volume discrimination learning in golden hamsters: Effects of the structure of complex rearing cages, Dev. Psychobiol. 14 (1981) 397-403.

[37] Thinus-Blanc C., Selection of relevant cues in volume discrimination by golden hamsters reared in different environments, Can. J. Psychol. 36 (1982) 520-526.

[38] Tsigos C., Chrousos G.P., Hypothalamicpituitary-adrenal axis, neuroendocrine factors and stress. A review, J. Psychosom. Res. 53 (2002) 865-871.

[39] Varty G.B., Paulus M.P., Braff D.L., Geyer M.A., Environmental enrichment and isolation rearing in the rat: Effects on locomotor behaviour and startle response plasticity, Biol. Psychiat. 47 (2000) 864-873.

[40] Veissier I., Le Neindre P., Cortisol responses to physical and pharmacological stimuli in heifers, Reprod. Nutr. Dév. 28 (1988) 553562.
[41] Veissier I., Le Neindre P., Garel J.P., Decrease in cow-calf attachment after weaning, Behav. Process. 21 (1990) 95-105.

[42] Veissier I., Gesmier V., Le Neindre P., Gautier J.Y., Bertrand G., The effects of rearing in individual crates on subsequent social behaviour of veal calves, Appl. Anim. Behav. Sci. 41 (1994) 199-210.

[43] Veissier I., Chazal P., Pradel P., Le Neindre P., Providing social contacts and objects for nibbling moderates reactivity and oral behaviour in veal calves, J. Anim. Sci. 75 (1997) 356-365.

[44] Veissier I., Boissy A., Nowak R., Orgeur P., Poindron P., Ontogeny of social awareness in domestic herbivores: a review, Appl. Anim. Behav. Sci. 57 (1998) 233-245.

[45] Veissier I., van Reenen C.G., Andanson S., Leushuis I.E., Adenocorticotropic hormone and cortisol in calves after corticotropinreleasing hormone, J. Anim. Sci. 77 (1999) 2047-2053.

[46] Veissier I., Boissy A., de Passillé A.M., Rushen J., van Reenen C.G., Roussel S., Andanson S., Pradel P., Calves' responses to repeated social regrouping and relocation, $\mathrm{J}$. Anim. Sci. 79 (2001) 2580-2593. 